\title{
A Case Study on the Dairy Project "Full Bucket" in Brazil: Socioeconomic and Environmental Characteristics in Areas Under Its Guidelines
}

\author{
Álvaro Antônio Xavier de Andrade ${ }^{1}$, Rafael da Silva Teixeira ${ }^{2}$, Rodrigo Nogueira de Sousa ${ }^{2}$, \\ Reinaldo Duque Brasil Landulfo Teixeira ${ }^{3}$, Dênis Antônio da Cunha ${ }^{1} \&$ Emanuelle Mêrces Barros Soares ${ }^{2}$ \\ ${ }^{1}$ Departamento de Economia Rural, Universidade Federal de Viçosa, Viçosa, Minas Gerais, Brazil \\ ${ }^{2}$ Departamento de Solos, Universidade Federal de Viçosa, Viçosa, Minas Gerais, Brazil \\ ${ }^{3}$ Universidade Federal de Juiz de Fora, Campus Governador Valadares, Governador Valadares, Minas Gerais, \\ Brazil \\ Correspondence: Rafael da Silva Teixeira, Departamento de Solos, Universidade Federal de Viçosa, Viçosa, \\ Minas Gerais, Brazil. Tel: 55-319-9331-4166. E-mail: teixeiramarky@yahoo.com.br
}

Received: November 28, 2018

doi:10.5539/jas.v11n3p515
Accepted: December 31, 2018 Online Published: February 15, 2019

URL: https://doi.org/10.5539/jas.v11n3p515

\begin{abstract}
Socioeconomic and environmental characteristics in areas under Brazilian Balde Cheio Project (BCP) were evaluated. Questionnaires were applied to identify productive and socioeconomic characteristics of small farmers, and farmers' perceptions on the implementation and operation of BCP. Soil and water samples were also taken. It seems that farmer's perception about the $\mathrm{BCP}$ is associated to their socioeconomic reality; while environmental issue does not have the same relevance. According to the farmers, it was verified increase of productivity, and financial income. All farmers agree that they have not followed carefully the NGO guidelines, which is a matter of concern, because the differences among reality farms. In studied soils were observed that organic carbon levels decreased in areas under the $\mathrm{BCP}$ management. The $\mathrm{NO}_{3}{ }^{2-}, \mathrm{Cl}^{-}$and $\mathrm{SO}_{4}{ }^{2-}$ concentrations in the waters samples were below the maximum stipulated by Brazilian environmental legislation. However, it should be highlighted that high nutrient addition and low $\mathrm{C}$ input in the system, can result in high losses of nutrients and also $\mathrm{CO}_{2}$ into the atmosphere.
\end{abstract}

Keywords: dairy production, chemical fertilization, GEE, sustainability, socioeconomic characteristics and environmental characteristics

\section{Introduction}

Balde Cheio Project (BCP) is carried out by Brazilian Agricultural Research Corporation (EMBRAPA), BCP was developed in 1998 by EMBRAPA Southern Livestock. This project seeks to train professionals who work with technical assistance and disseminate technologies associated with dairy production in Brazil. Among the available technologies that aim to enhance pasture production and to increase the quality and quantity of the food supplies, are: (i) the establishment of paddocks with an irrigation system installed; (ii) management of pasture with chemical fertilization associated with soil acidity correction. The use of these technologies has increased dairy production and the income of the producers (Camargo et al., 2006a, 2006b).

According to the Brazilian Institute of Geography and Statistics (IBGE, 2014), data from the United States Department of Agriculture (USDA) indicate that Brazil was the world's fifth largest milk producer in 2014, after the European Union, India, the United States and China. In the same year, the southern region occupied the first position in the ranking of Brazilian regions, with $34.7 \%$ of national production. However, considering state production, Minas Gerais is the country's main dairy basin: in 2014 this state produced 9.37 billion liters of milk, corresponding to $77 \%$ of all production in the southeast region and $26.6 \%$ of total Brazilian production. From the perspective of productivity during one year, the southern states presented an average of 2,907 $\mathrm{L} \mathrm{cow}^{-1}$, while in Minas Gerais this average reached only $1,645 \mathrm{~L} \mathrm{cow}^{-1}$, close to the Brazilian average of 1,526 $\mathrm{L} \mathrm{cow}^{-1}$ (IBGE, 2014). 
BCP was implemented by the Federation of Agriculture and Livestock of the State of Minas Gerais (FAEMG System). According to this institution, it "represents rural producers throughout the Minas Gerais state", joining "forces to defend the political, economic and social interests of category" through 379 labor unions, benefiting more than 400 thousand small, medium and large farmers. In addition, the institution has a partnership with the National Rural Apprenticeship Service (SENAR) to train farmers through "Rural Professional Training" and "Social Promotion" (SISTEMA FAEMG, 2017).

The institutions working with technical assistance aiming to achieve increase in a dairy production and the income of the producers decided to implement the BCP. In 2015, the BCP was present in 320 of the 853 municipalities of Minas Gerais, serving 2,500 small farms (SISTEMA FAEMG, 2015). Data from the IBGE (2006) indicate that in this state there are 551,617 small farms, that is, approximately $0.45 \%$ working with the $\mathrm{BCP}$. However, despite the merit attributed to the BCP (increase of production, productivity, and financial income of the small farms); it recommends intensive pasture management through chemical fertilization use which is worrying, since this type of management can alter soils characteristics that determine in long term its productive capacity. Borges et al. (2011) emphasized that BCP were not efficient as a vector promoting environmental sustainability.

To Jenny et al. (2005), "Sustainability refers to the capacity of human systems to provide for the full range of human concerns in the long term". Considering this, the adequate soil management is a crucial action to maintain the sustainability of any agricultural system. Soils are the most basic of natural resources and the inappropriate management and indiscriminate use of chemicals have contributed to some severe global environmental issues, e.g., volatilization losses and contamination of natural waters by sediments and agricultural fertilizers and pesticides (Lal \& Logan, 1982). Besides, in soils with low clay content, as in this research area, it means lower nutrient retention capacity, increasing the chance of nutrients leaching, and a low capacity of soil organic matter (SOM) protection.

SOM represents important reservoir of carbon (C), which can be strongly affect by soil management (Baldock, 2007). Nowadays, soil $\mathrm{C}$ sequestration has been considered as mitigation measure, which can be an important strategy for milk production systems considering their $\mathrm{CO}_{2}$ equivalent per $\mathrm{kg}$ of milk produced. According to Rotz et al. (2010) is estimated that 0.37 to $0.69 \mathrm{~kg}$ of $\mathrm{CO}_{2}$ equivalent per $\mathrm{kg}$ of milk produced, is released to atmosphere. In addition, SOM influences the chemical, physical and biological characteristics of the soil (Batjes, 2014), such as: nutrient release, water storage and physical structure, which are essential to the maintenance of soil productive capacity and the system resilience (Lal, 2008).

SOM is also source of Nitrogen (N), approximately $95 \%$ of N is organic-N (Schulten \& Schnitzer, 1998). N has an important role in the production and plant residues decomposition (Manzoni et al., 2012; Eisenlord et al., 2013) influencing SOM formation (Janssens et al., 2010).

In cultivated areas $\mathrm{N}$ replacement is largely accomplished by chemical fertilization. The source of $\mathrm{N}$ used in the areas managed by the BCP is urea, a fertilizer whose hydrolysis is mediated by a soil enzyme (urease), which results in the formation of the ammonia gas $\left(\mathrm{NH}_{3}\right)$, which can be lost by volatilization (Moreira \& Siqueira, 2006). When the urea is left in the surface, and with favorable conditions for urease activity, this loss can reach to $75 \%$. In the soil, $\mathrm{NH}_{3}$ is converted to the ammoniacal form $\mathrm{N}$-ammonium $\left(\mathrm{NH}_{4}{ }^{+}\right)$, which is absorbed by the plants. In turn, high doses of urea increase the $\mathrm{NH}_{4}{ }^{+}$availability and can cause the intensification of the nitrification process, resulting in $\mathrm{N}$-nitrate $\left(\mathrm{NO}_{3}^{-}\right)$leaching and consequent $\mathrm{N}$ losses of the system (Luna et al., 2013), which can contaminate water resources. Therefore, depending on management, fertilization of pastures can affect negatively the environment and compromise the sustainability of agricultural production. High doses of $\mathrm{N}$ can result in increases and decreases in SOM. Furthermore, high doses of nutrients can accelerate microbial degradation of native SOM, due to the alteration of soil microbial activity (Kuzyakov, 2010).

The search for sustainability in agricultural production, besides environmental aspects, should include the socioeconomic reality of involved farmers. In the last years, the researchers on environmental studies had the sensitivity of include individuals and their characteristics as object of their analysis (Silva Filho, 2010; Amarante Junior \& Silva, 2013). The knowledge about the realities surrounding the farmers, and their perceptions about the object under study, is directly related to their daily actions and can help in the formulation and adaptation of government projects and actions, such as the BCP.

The municipality of São Felix de Minas, in the eastern state of Minas Gerais (MG), Brazil, was selected to carry out the present work, with the following objectives: i ) to know the small farmers' perceptions regarding the $\mathrm{BCP}$ and the realities involved in its implementation; ii) to evaluate the impact of managed pasture under theBCP 
guidelines on soil $\mathrm{C}$ and $\mathrm{N}$ levels in relation to other pastures in the small farms; iii) to evaluate water samples collected in areas with and without influence of the BCP.

\section{Methods}

\subsection{Use of Questionnaires}

In order to identify the productive and socioeconomic realities, as well as to diagnose of the farmers' perceptions and knowledge about the guidelines and techniques of the Balde Cheio Project, questionnaires were applied with an individual of each of these small farms. The questionnaires were composed of 51 closed and open questions, which allowed the owners to respond with their own language and ensure the freedom of expression of their opinions on the questions asked (Marconi \& Lacatos, 2003). The use of this technique made it possible to identify the realities and knowledge of the farmers on: i) access to the BCP; ii) frequency of visits and work carried out by the NGO on the small farms; iii) access and use of farmers to rural credit; iv) benefits arising from the BCP implementation according to farmers' perceptions; and v) pasture areas managed and not managed under the BCP guidelines.

\subsection{Soil and Water Analysis}

The soil samples were taken (4 composed sample) from the $0-10 ; 10-20 ; 20-40 ; 40-60$ and $60-100 \mathrm{~cm}$ layers in paired areas under pasture cultivation, areas under Balde Cheio Project, and areas under regular management. The experimental design was considered as completely randomized, with the collection of four replicates. The samples were air-dried and passed through a 2.0-mm mesh sieve (ADFS - air-dried fine soil) for further chemical analyzes and soil granulometry (Table 3). The organic carbon (OC) was determined by the wet oxidation method with external heating (Yeomans \& Bremner, 1988), total nitrogen (TN) using the Kjeldahl method, modified by Tedesco (1985), N-NH 4 through the proposed method by Kempers and Zweers (1986) and $\mathrm{N}-\mathrm{NO}_{3}$ as described by Yang et al. (1998). Organic nitrogen (ON) levels were obtained by subtracting the $\mathrm{N}-\mathrm{NH}_{4}$ and $\mathrm{N}-\mathrm{NO}_{3}$ levels from $\mathrm{TN}$ levels.

Water samples were collected at two different points within the small farms, before (B-BCP) and after (A-BCP) from the pasture areas managed according to $\mathrm{BCP}$, following the topography. They were collected in plastic containers $(0.5 \mathrm{~L})$ at four points within each existing watercourse inside the small farms. The samples were passed on a cellulose acetate filter with $0.45 \mu \mathrm{m}$ pores and then injected into the ion-exchange chromatograph (DX 600, Dionex, Sunnyvale, CA, USA) for the determination of nitrate anions $\left(\mathrm{NO}_{3}{ }^{2-}\right.$ ), chloride $\left(\mathrm{Cl}^{-}\right)$and sulfate $\left(\mathrm{SO}_{4}{ }^{2-}\right)$. The anions were detected by conductivity (Electrochemical Detector ED 50, Dionex).

\subsection{Statistical Analysis}

The analysis of variance (ANOVA) of data from TOC, TON, N-NO Farmland was performed. The data of $\mathrm{NO}_{3}{ }^{2-}, \mathrm{Cl}^{-}$e $\mathrm{SO}_{4}{ }^{2-}$ and $\mathrm{SO}_{4}{ }^{2-}$ concentration in the water samples, besides the analysis of variance (ANOVA), the mean differences were accessed by a post-hoc Tukey's test $(\alpha=5 \%)$.

\section{Results and Discussions}

\subsection{Socioeconomic and Environmental Description of the Surveyed Municipality}

The study was carried out in the municipality of São Félix de Minas-MG, Brazil (18 $35^{\prime} 25^{\prime \prime}$ S 41 $29^{\prime} 5^{\prime \prime}$ W), which represents eastern Minas Gerais. According to the United Nations Development Program (UNDP, 2013), $42.25 \%$ of the 18 -year-olds working in this municipality were employed in the agricultural sector, making this the main economic activity. In São Félix de Minas the Balde Cheio project has been implemented by a Non-Governmental Organization (NGO), as in fifteen municipalities in the east of Minas Gerais.

The Secretariat of Agriculture and Environment of São Félix de Minas (SAPEMA) reported that in 2008 it had 23 small farms registered in the BCP. However, according to SAPEMA, due to the organizational requirement and the intense need for workforce, in July 2015, when this research was carried out, only nine small farms were registered in the project. Nevertheless, it was informed by the secretariat that only five of these small farms were receiving technical assistance to operationalize the BCP. Thus, it was decided to evaluate the five small farms that were being assisted by the NGO. This institution funded the technical assistance services through funds from Banco do Brasil Foundation, and from the assisted farmers, who contributed financially on a monthly basis to benefit from visits and technical assistance offered by the NGO.

Data from UNDP (2013) indicate that some socioeconomic indices of the population of São Félix de Minas are below the Brazilian average and the state of Minas Gerais itself (Table 1). 
Table 1. Comparativesocioeconomic data: Brazil, Minas Gerais and São Félix de Minas

\begin{tabular}{llll}
\hline Indices in the year 2010 & Brazil & Minas Gerais & São Félix de Minas Minas \\
\hline Illiteracy-18 years and over & $10.19 \%$ & $8.83 \%$ & $24.33 \%$ \\
$\begin{array}{l}\text { Average income of employed persons in August, } \\
\text { independent of the sector-18 years or more (R\$) }\end{array}$ & R \$ 1,296.19 & R \$ 1,165.54 & R $\$ 515.39$ \\
Percentage of extremely poor population & $6.62 \%$ & $3.49 \%$ & $10.99 \%$ \\
Percentage of the poor & $15.20 \%$ & $10.97 \%$ & $30.01 \%$ \\
\hline
\end{tabular}

Source: Elaborated based on data from UNDP (2013).

Thus, based on studies about the importance of education in the field for sustainable local development, and for the understanding and operationalization of public policies by local populations, as pointed out by Xavier (2012), the diagnosed situation for the municipality in this research may be directly related to the farmers' perception of the operationalization and the importance of the BCP. In addition, the high percentage of people living in poor conditions may also bias their perceptions on the importance of the BCP.

The native vegetation of the studied region was originally classified as Seasonal Semi-deciduous Forest, belonging to the Atlantic Forest biome (Veloso et al., 1991; Rizzini, 1997). However, with less than one hundred years of occupation, the east of Minas Gerais has undergone one of the most serious and intense processes of environmental degradation in the history of Brazil. Violence, land concentration, and the rapid loss of biodiversity are hallmarks of this occupation process. The so-called "East backlands" were colonized through the extermination of indigenous peoples living between the rivers Watu (Doce) and Cricaré (São Mateus), and also by the intensive and predatory exploitation of natural resources. According to Espíndola (2005), these actions characterize the current landscapes of the researched region; where the existence of extremely degraded pastures, exposed soils, and unprotected streams are easily perceived (Figure 1).

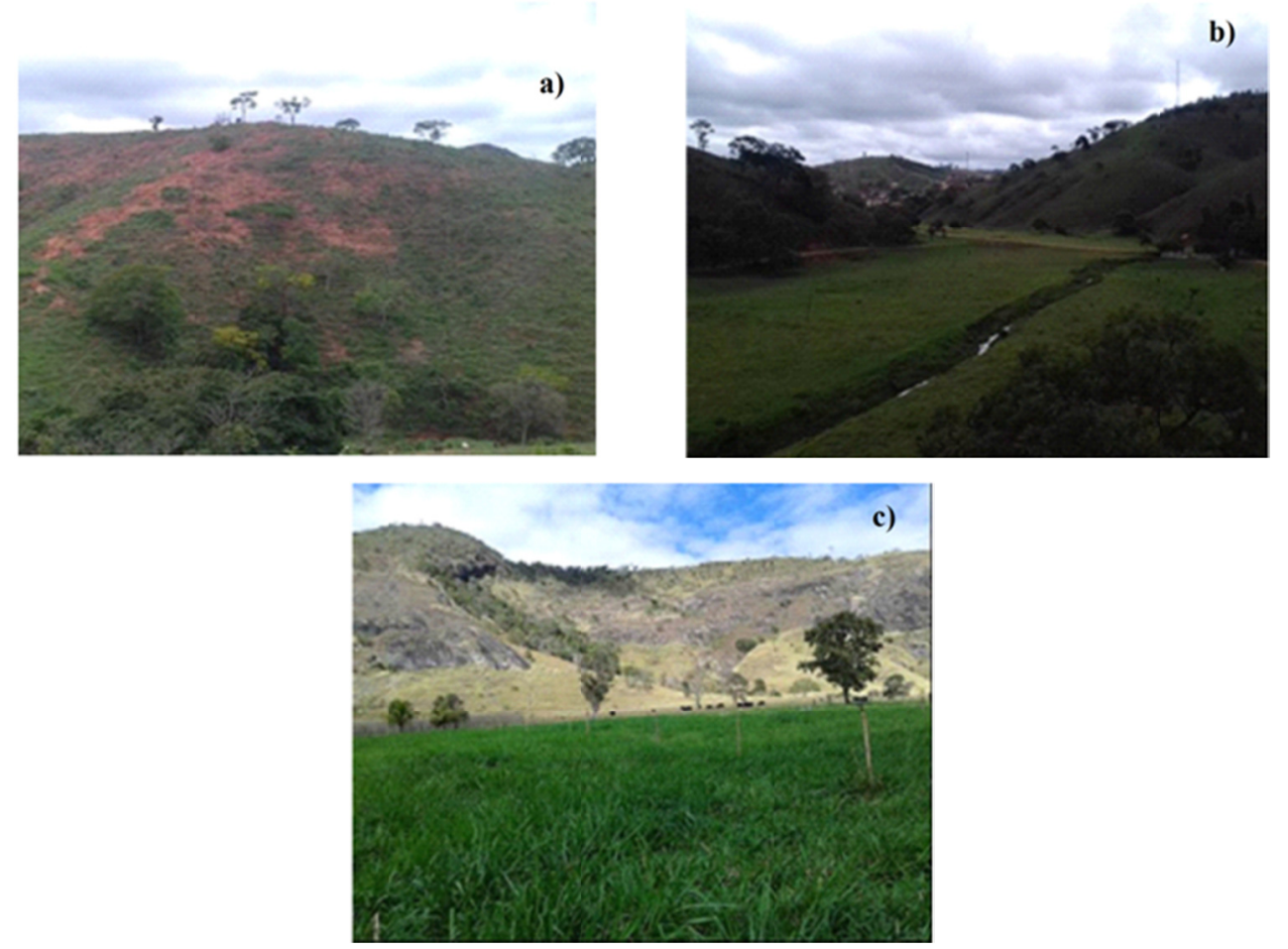

Figure 1. Degraded pasture area (a); unprotected watercourse in pasture area (b) and pasture areas, including unmanaged and managed by the BPC (c) in São Félix de Minas, Minas Gerais-Brazil

The local climate is Cwa (humid temperate climate with dry winter and hot summer) according to Köppen's classification. In each farmland there were pasture areas, unmanaged and managed, by the Balde Cheio Project, 
which are easily identified due to the color and size of the grass, since the research was carried out in the dry season of the eastern Minas Gerais (Figure 1 and Table 2).

Table 2. Description and history of the use of pasture areas in five farmlands located in São Félix de Minas - MG, Brazil

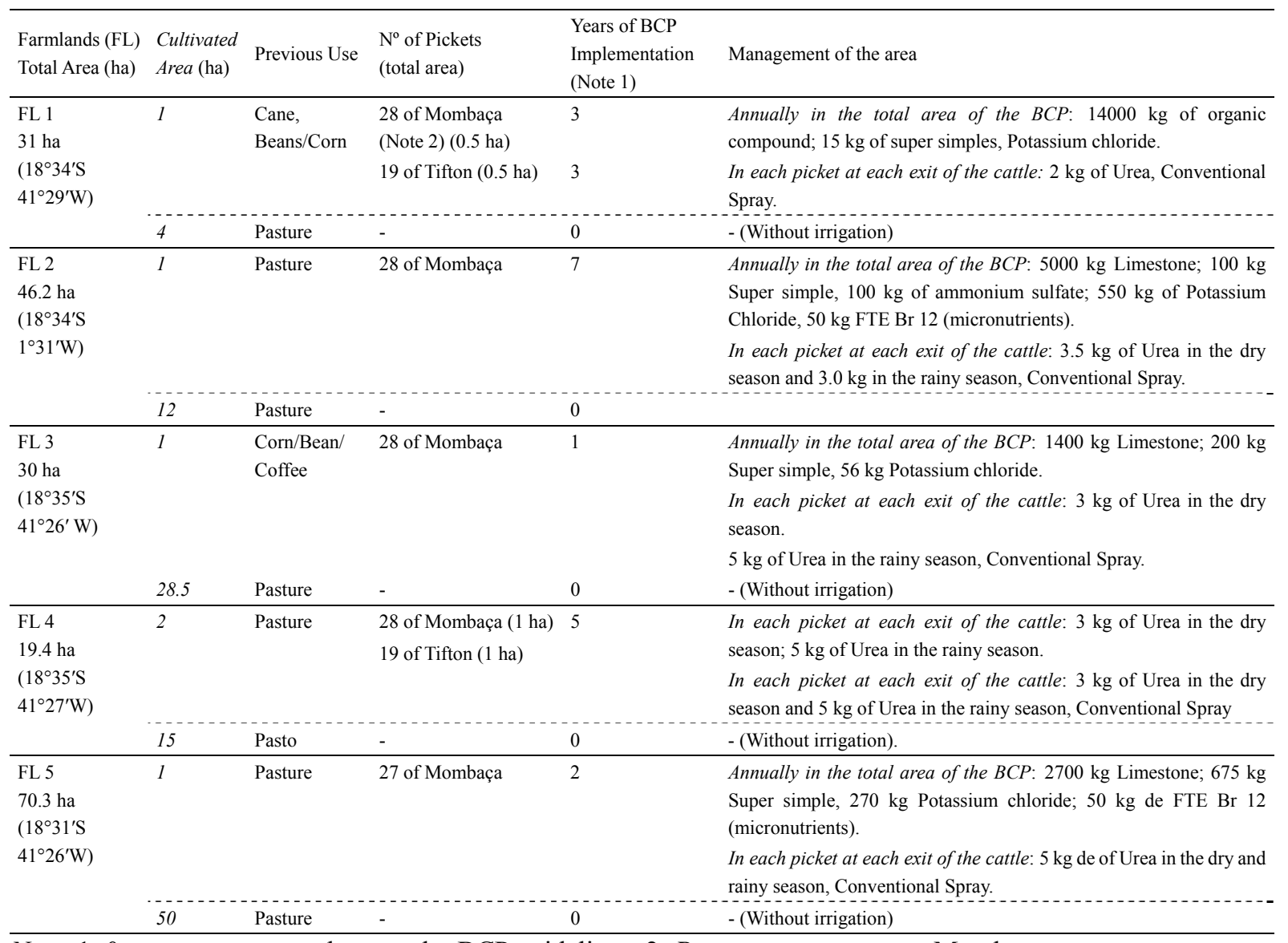

Note. 1: 0 years-areas never been under BCP guidelines; 2: Panicum maximum cv. Mombasa.

\subsection{Aspects Related to the Socioeconomic and Productive Realities of the Small Farms and Farmers' Perceptions on the Implementation and Operation of the Balde CheioProject (BCP)}

Considering the socioeconomic realities, the visited small farms resemble the general reality of the entire municipality São Félix de Minas, among which we can list: incipient formal education, insufficient technical knowledge, and problems related to lack of financial resources. Thus, the perception of farmers about the BCP can be directly linked to reality in the search for socioeconomic improvements, in which environmental issues do not have the same relevance on the activities developed, although there are some areas preserved in the farms.

Four farmers informed that they have learned about the project through SAPEMA. The others said that they came to know about it through neighbors. Only two of them said that they had been trained to implement and work with the $B C P$ and that the training was carried out by SAPEMA/and NGO; also one of these farmers highlighted the participation of the State Company for Technical Assistance and Rural Extension (EMATER-MG) in these trainings.

All the farmers confirmed that they received technical assistance from the NGO and described that the technician of this institution have visited their farms on a monthly basis. Regarding the activities developed by, the farmers answered that their work is focused mainly on three aspects: pasture production (irrigation system and soil sampling in the BCP area for fertilization); animal husbandry (food, sanitary and reproductive care) and aid to the financial closure of the dairy activity. Only one farmer mentioned that the technician also advised on environmental issues, also collaborating with the donation of plant seedlings for the recovery and conservation 
of springs and environmental preservation areas. It is worth mentioning that this farmer also pointed out that the seedlings were produced by the technician.

Regarding the access and use of rural credit, all farmers accessed the National Program for Strengthening Family Agriculture (PRONAF), created by the federal government in 1996 to assist Brazilian family farming development, defined in Federal Law 11.326 of 2006. Access to credit, in all small farms, was related to cattle purchase to improve herds and increase the dairy productivity of farms. The loan was never invested to the preservation and/or recovery of degraded areas.

The most farmers agree that they did not follow carefully the NGO guidelines. The reasons for that were centered on the lack of work force and financial resources to carry out the activities, as SAPEMA had pointed out when describing the abandonment of the project by more than $70 \%$ of the farmers who joined it in 2008 . However, it was possible verify that some farmers in São Félix de Minas have followed the guidelines of the $\mathrm{BCP}$. Although they did not have the necessary technical assistance, they repeat the actions of the farmers that are or were in the project. This fact is a matter of concern, because the realities and characteristics of the small farms and of the herds can be different. The management would have to be differentiated for each one of these small farms.

It is important to mention, that several studies in Brazil point out that farmers, due to lack of knowledge or fear of not obtaining the desired productivities, do not follow the technical guidelines and end up having financial losses or contaminating natural resources due to the inadequate use of chemical inputs (Aleixo, 2012; Scheid \& Kessler, 2012; Costa et al., 2012).

In relation to the benefits of the implementation of the $\mathrm{BCP}$, according to the farmers, the project has been fundamental for the continuity of dairy activity in the small farms. All of the farmers answered that the main benefit of the project is related to increase of family financial income. Three of the producers pointed out that the $\mathrm{BCP}$ makes it possible to increase animal stocking and, consequently, production. Only one of them highlighted the benefit of the possibility provided by the project of increasing the technical knowledge for milk production.

The relevance given to economic issues was also diagnosed in the information provided by SAPEMA about the BCP. According to the secretariat, the average production per cow in São Félix de Minas jumped from $3.74 \mathrm{~L}$ day $^{-1}$ in 2006 to $6.89 \mathrm{~L}$ day $^{-1}$ in 2014, evolution attributed to the technologies coming from the Balde Cheio Project. Although SAPEMA carried out several environmental projects, such as the mapping of 246 existing springs in the municipality and the enclosure of 40 of these in partnership with the state government of Minas Gerais, the environmental issues do not seem to have been completely aligned by the guidelines of the BCP.

Besides of the relevance of economic of BCP, even more in this municipality, according to Aleixo et al. (2012), when thinking about agricultural sustainability, it is necessary to have "specific precautions to protect the environment in order to minimize adverse effects on soil and water". In this context, as indicated by studies performed in Brazil, it is imperative that all actors involved in activities, farmers, technicians, and institutions assume their roles, and perform their functions also thinking about the environmental aspect, intrinsically linked to sustainability, and not just considering the socioeconomic issues inherent to it, which represents a common fact in Brazilian agricultural production systems (Moura, 2002; Rubia et al., 2014).

\subsection{Aspects Related to Pastures Managed Under the Balde Cheio Project Guidelines (BCP) on the Soil C and N Levels in Relation to Pastures Not Managed Under the Balde Cheio Project Guidelines (PNMBCP)}

Total organic C (TOC) decreased in areas under BCP, in the Farmland $1(0-10$ and 40-60 cm), $2(0-10$ and 10-20 $\mathrm{cm})$ and $3(10-20 \mathrm{~cm})$, comparing to areas that were not under this management. In the Farmland 4, the same effect was observed in the 10-20 cm layer, but the BCP area had a higher content in the 40-60 cm layer (Figure 2). The most intense effects on the reduction of TOC were observed in the $0-10 \mathrm{~cm}$ layers of the Farmlands 1 $(37.8 \%)$ and $2(49 \%)$, with three and seven years of the BCP implementation, respectively. In Farmland 3, with one year BCP implementation, there was a reduction in the $10-20 \mathrm{~cm}$ layer with a loss of $25 \%$ of the initial TOC (Figure 2). 


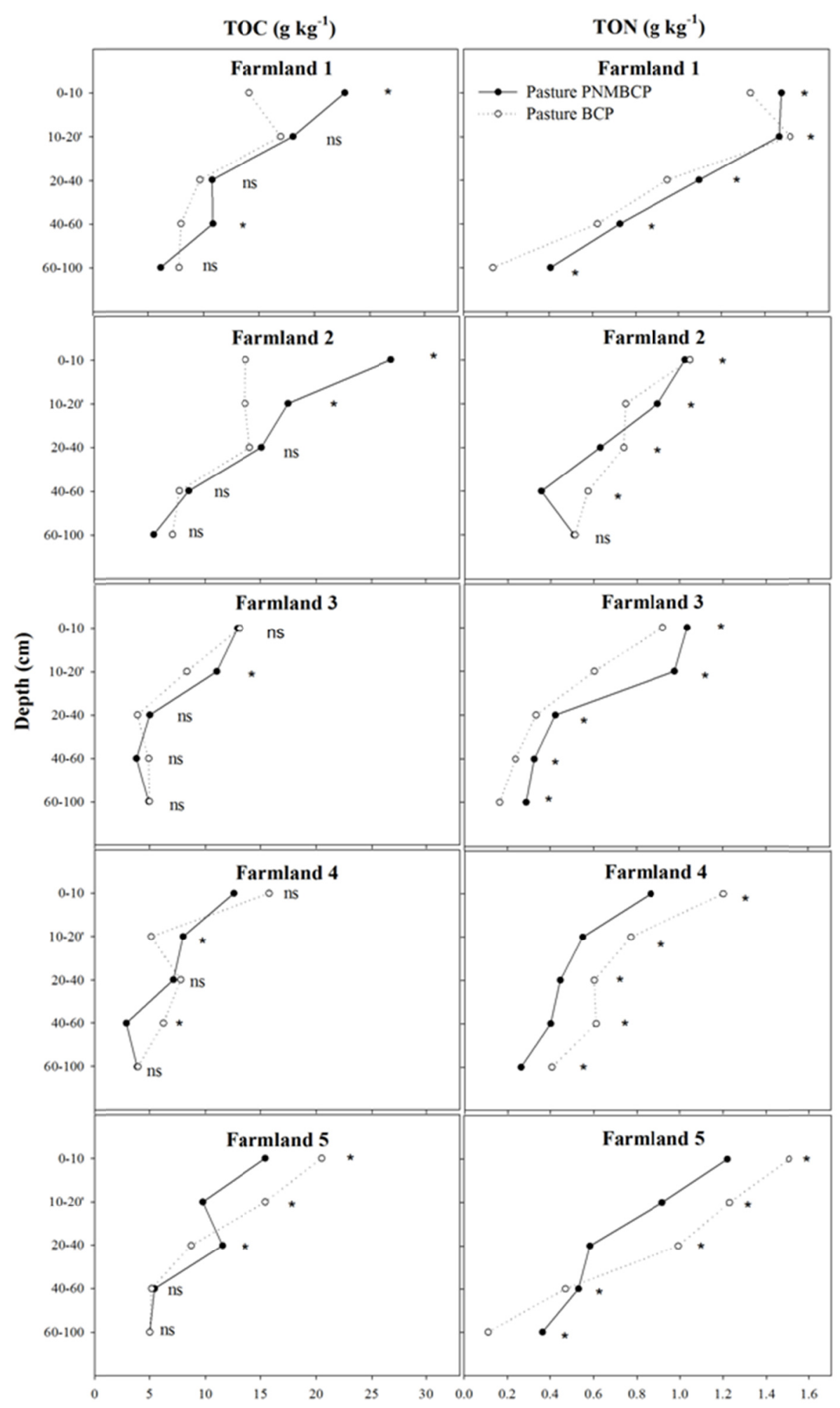

Figure 2. Total organic carbon (TOC, $\mathrm{g} \mathrm{kg}^{-1}$ ) and Total organic nitrogen (TON, $\mathrm{g} \mathrm{kg}^{-1}$ ) in the soil depths of pastures not managed under the Balde Cheio Project guidelines (PNMBCP) and pastures managed under the Balde Cheio Project guidelines (BCP) in the five small farms located in São Félix de Minas-MG, Brazil. ${ }^{\text {ns }}$ Represents no difference and *represents the difference between the areas within each soil layer by the analysis of variance of the data $(\alpha=5 \%)$ 
Soil $\mathrm{C}$ levels depend on the annual organic $\mathrm{C}$ variation of represented by: $d C / d t=K_{l} A-K_{2} C$, where, $K_{l} A$ is the $\mathrm{C}$ input and $K_{2} C$ is loss of soil C. In grazing areas, the root system is an important pathway for $\mathrm{C}$ into the soil, via root biomass and rhizode positions (exudates, secretions, mucilages and cell lysates) (Kuzyakov \& Jones, 2006). Another possible source of $\mathrm{C}$ is the manure of ruminants that are continuously added naturally during grazing, which may contribute to the increases in TOC in soils (Rusinamhodzi et al., 2013). The inputs above ground are not effective, since much of the material is destined for forage production or is defoliated during grazing. Thus, increases in biomass production does not necessarily increase $\mathrm{C}$ stocks in the system, especially for species that maintain a low root/shoot ratio (Kuzyakov \& Domanski, 2000; Rasse et al., 2005), which may be altered by grazing intensity. In addition, Janssens et al. (2010) point out that the high availability of $\mathrm{N}$ in the soils can lead to less investment in the root system.

Thus, in the present work, the inputs of $\mathrm{C}$ on the system may not be effective, additionally, losses may occur, which directs the equilibrium of the equation to a negative $\mathrm{C}$ balance. Soil $\mathrm{C}$ losses can occur in the fragments where $\mathrm{C}$ is newly added, and also by the decomposition of native SOM. The losses of $\mathrm{C}$ observed in Farmlands 1 , 2, 3 and 4 after the BCP implementation may result from the priming effect. Phenomenon characterized by a stimulus to the microbial degradation of the native SOM, due to the alteration of the microbial activity of the soil (Kuzyakov, 2010). In this case, the set of factors of the intensive harvest (soil preparation and correction, nitrogen fertilization every 28 days, and irrigation), together with the greater rhizode positions stimulated by the continuous regrowth of the pasture, may have favored growth and microbial activity in the soil. The TOC losses of the system were verified up to a maximum of $40 \mathrm{~cm}$, a region of greater influence of the soil preparation and grass root exploitation, and there was no evidence of significant effects at greater depths.

The positive effect on TOC level in the area under the BCP of Farmland 5 may be associated with slightly higher clay content in relation to PNMBCP, resulting in increases of 33\% and $58 \%$ in layers of $0-10$ and $10-20 \mathrm{~cm}$. The association of the organic compounds of the soil with the mineral fraction provides the formation of organo-mineral complexes, being responsible for the greater stabilization control of SOM in long term. This protection of SOM, associated with soil minerals, occurs by the sorption on the surface of minerals, and by greater soil aggregation, which occurs in a relatively short period of time (Andrews et al., 1994). Soil aggregation is favored by the increase of SOM by forming aggregates (Angers et al., 1997), providing greater difficulty to microbial access. In fact, in the present study, the highest levels of TOC in the $0-10 \mathrm{~cm}$ layer were observed in small farm 1 (22.71 $\mathrm{g} \mathrm{kg}^{-1}$ PNMBCP), 2 (26.83 $\mathrm{g} \mathrm{kg}^{-1}$ PNMBCP) and 5 (20.48 $\mathrm{g} \mathrm{kg}^{-1} \mathrm{BCP}$ ) (Figure 2), which presented higher clay levels (Table 3).

Pasture management under the BCP guidelines in farmlands 4 and 5 provided a $0-10 \mathrm{~cm}$ soil increase in $39.5 \%$ and 24\% TON, respectively (Figure 2). While in areas 1 and 3, the areas of PNMBCP, presented TON levels of $10.5 \%$ and $12 \%$ higher in the relations to the area managed by the BCP (Figure 2).

Observing the TON levels along the soil profile (20-40, 40-60 and 60-100 cm layers), the trends were similar to those observed in the TOC (Figure 2). These differences are closely related to the TOC levels; however, it should be considered that even in the BCP areas large $\mathrm{N}$ inputs occur via fertilizers, doses that vary from 50 to $63 \mathrm{~kg}$ $\mathrm{ha}^{-1}$ of N-Urea at each grazing cycle (every 28 days). The soils of small farms 1 and 3 presented lower TON levels in relation to the areas of PNMBCP. Considering that increases in SOM were not significant, increases in TON were not observed in the same way. The TON level of the soil comprises $95 \%$ of the Total Nitrogen (TN) (Schulten \& Schnitzer, 1998). Thus, the higher clay level in the soil allows a greater protection to the microbial degradation and, consequently, higher levels of $\mathrm{N}$ in the soil (Jindaluang et al., 2013).

According to the Manual of Recommendation of Fertilization and Liming of the State of Minas Gerais (Ribeiro et al., 1999), in pasture areas with high technological level it is recommended to apply 100 to $150 \mathrm{~kg} \mathrm{ha}^{-1}$ of N, so that it does not exceed $50 \mathrm{~kg} \mathrm{ha}^{-1}$ application ${ }^{-1}$. For rotation systems of high technological level and under irrigation, it is recommended to add $300 \mathrm{~kg} \mathrm{ha}^{-1}$ year of $\mathrm{N}$, fractionated in six applications.

In the BCP surveyed area, a mean of $47.7 \mathrm{~kg} \mathrm{ha}^{-1}$ month $^{-1}$ of $\mathrm{N}$ was applied, totaling $572 \mathrm{~kg} \mathrm{ha}^{-1}$ year ${ }^{-1}$ of N (Table 2). With the reestablishment of a new cycle, occurring every 28 days, there will be a great export of $\mathrm{N}$ added, but the potential losses will accumulate throughout the year of cultivation, possibly leading to a considerable loss of $\mathrm{N}$, especially in favorable water conditions, as occurs in BDP areas due to constant irrigation.

Analyzing the ions $\mathrm{NO}_{3}{ }^{2-}, \mathrm{Cl}^{-}$, and $\mathrm{SO}_{4}{ }^{2-}$ concentrations present in the waters before (B-BCP) and after (A-BCP) of the areas where the $B C P$ was implemented, it was observed that only in Farmlands 1 and 2 the concentrations were higher in A-BCP (Figure 3). 
The A-BCP waters in Farmland 1 presented $113 \%$ and 140\% (A-BCP1 and A-BCP2, respectively) higher $\mathrm{Cl}^{-}$ concentration, while to $\mathrm{NO}_{3}{ }^{2-}$ concentration the $\mathrm{B}-\mathrm{BCP}$ were $16 \%$ and $37 \%$ (A-BCP1 and A-BCP2 respectively) higher compared to B-BCP. In Farmland 2 only $\mathrm{Cl}^{-}$concentrations were higher in relation to $\mathrm{B}-\mathrm{BCP}$ (A-BCP1: $41 \%$ higher) (Figure 3). The highest $\mathrm{NO}_{3}{ }^{2-}$ concentrations only in the A-BCP waters in Farmlands 1 and 2 indicates the occurrence of later leaching of $\mathrm{NO}_{3}{ }^{2-}$ to the water table, whereas in small farms 2,4 and 5 this process was not longer detected in the A-BCP waters (Figure 3).
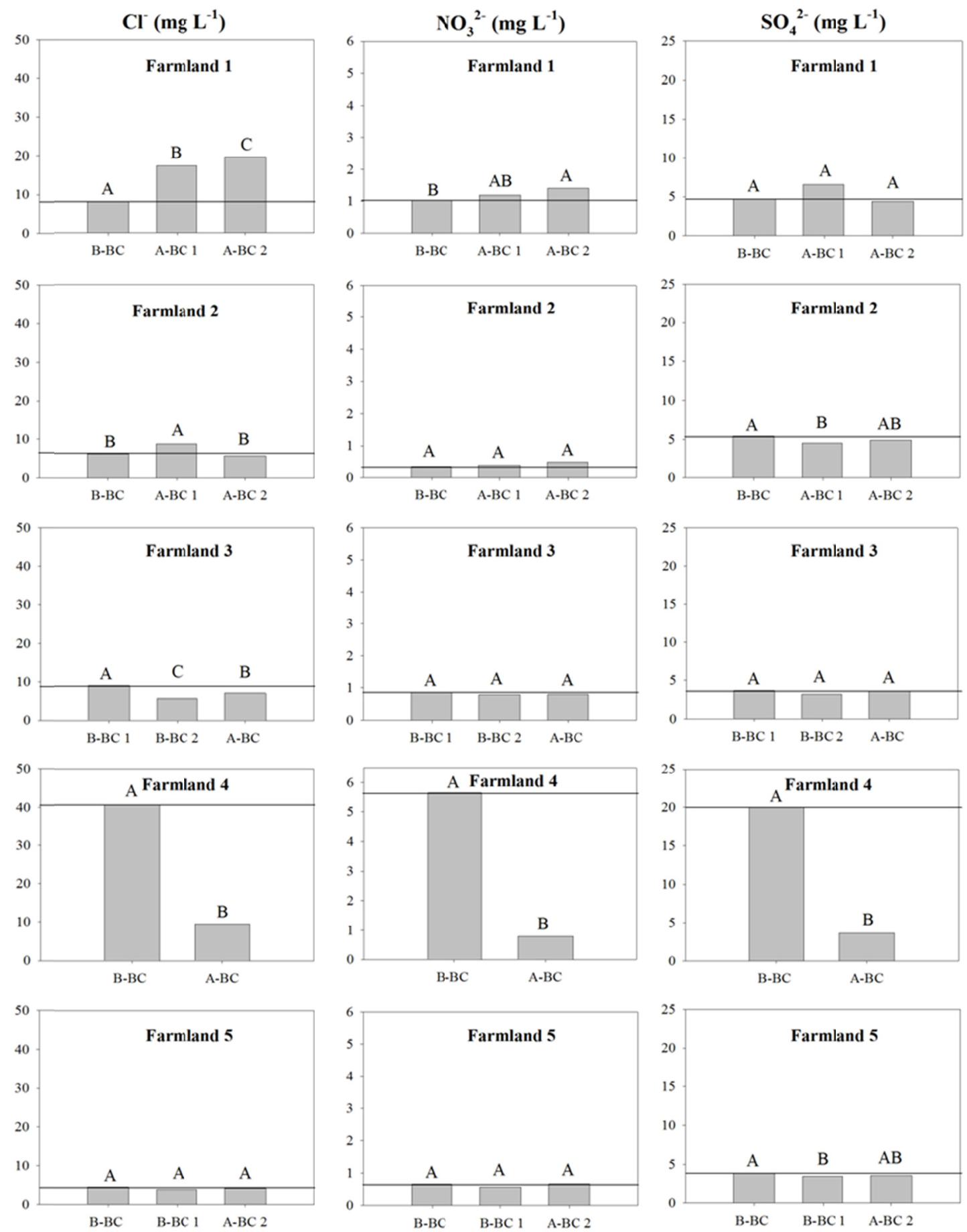

Figure 3. Nitrate $\left(\mathrm{NO}_{3}{ }^{2-}, \mathrm{mg} \mathrm{L}^{-1}\right)$, Chloride $\left(\mathrm{Cl}^{-}, \mathrm{mg} \mathrm{L}^{-1}\right)$ and Sulphate $\left(\mathrm{SO}_{4}{ }^{2-}, \mathrm{mg} \mathrm{L}^{-1}\right)$ concentrationsin in water at collection points before (B-BCP) and after (A-BCP) of the cultivated area of the Balde Cheio Project in the five farmlands located in São Félix de Minas-MG. Different capital letters denote significant differences among the collection points within each Farmland by the Tukey's test $(\alpha=0.05)$ 
The urea used as a $\mathrm{N}$ source in the $\mathrm{BCP}$, may have $\mathrm{NO}_{3}{ }^{2-}, \mathrm{Cl}^{-}$and also $\mathrm{SO}_{4}{ }^{2-}$ concentrations in the form of impurities, and these, as well as $\mathrm{NO}_{3}{ }^{2-}$, may be leached from the soil system. The maximum $\mathrm{Cl}^{-}$and $\mathrm{SO}_{4}{ }^{2-}$ concentrations or domestic use of water, recreation, and irrigation are $10 \mathrm{mg} \mathrm{L}^{-1}, 250 \mathrm{mg} \mathrm{L}^{-1}$, and $250 \mathrm{mg} \mathrm{L}^{-1}$, respectively, according to Article 4 of Resolution n. 20 of the National Environment Council (CONAMA, 1986). In this way, the concentrations found in the waters of the five studied farmlands are below the maximum concentrations stipulated by the legislation.

\section{Conclusions}

The knowledge about farmers realities and their perceptions are directly related to their daily actions and can help in the formulation and adaptation of government projects and actions.

All farmers agree that they have not followed carefully the NGO guidelines. This fact is a matter of concern, since the reality farms is different and deserves special attention in each situation.

The results of this study indicate the need of highlight the importance of environmental issues, as comprised by BCP guidelines (to search for the sustainability of milk production).

In general, it was verified that the implementation of the $\mathrm{BCP}$ led to decreases in the total organic $\mathrm{C}$ levels of the soil in the areas with lower clay content and low physical and chemical protection capacity, and that the large amount of $\mathrm{N}$ added in pastures did not reflect higher levels of organic $\mathrm{N}$.

Since the nitrate $\left(\mathrm{NO}_{3}{ }^{2-}\right)$, chloride $\left(\mathrm{Cl}^{-}\right)$and sulphate $\left(\mathrm{SO}_{4}{ }^{2-}\right)$ concentrations found in the waters were below the maximum concentrations stipulated by Brazilian legislation, until the moment the sampled water did not presented risks for human and animal consumption.

\section{References}

Aleixo, A. D., Brito, Z. R., Sato, S. A. S., Oliveira, N. D. A., \& Melo, J. V. (2016). Agricultura e responsabilidade socioambiental: Um estudo com agricultores do municipio de Cacoal/RO. XXXII Encontro Nacional de Engenharia de Produção.

Amarante Júnior, O. P., \& Silva, J. K. F. (2013). Percepção ambiental de moradores da bacia do rio anil. Acta Tecnológica, 8, 47-55.

Andruschkewitsch, R., Geisseler, D., Dultz, S., Joergensen, R., \& Ludwig, B. (2014). Rate of soil-aggregate formation under different organic matter amendments-A short-term incubation experiment. J. Plant Nutr. Soil Sci., 177, 297-306. https://doi.org/10.1002/jpln.201200628

Angers, D. A., Recous, S., \& Aita, C. (1997). Fate of carbon and nitrogen in water-stable aggregates during decomposition of ${ }^{13} \mathrm{C}{ }^{15} \mathrm{~N}$-labelled wheat straw in situ. Eur J. Soil Sci., 48, 295-300. https://doi.org/ 10.1111/j.1365-2389.1997.tb00549.x

Baldock, J. A. (2007). Composition and cycling of organic carbon in soil. In P. Marschner, \& Z. Rengel (Eds.), Nutrient Cycling in Terrestrial Ecosystems (pp. 1-35). Springer Verlag, Berlin Heidelberg. https://doi.org/ 10.1007/978-3-540-68027-7_1

Batjes, N. H. (2014). Total carbon and nitrogen in the soils of the world. Eur J. Soil Sci., 65, 10-21. https://doi.org/10.1111/ejss.12114_2

Borges, M. S., Guedes, C. A. M., \& Assis, R. L. (2011). Um estudo do "Projeto Balde Cheio" como vetor de desenvolvimento sustentável do pequeno produtor de leite. Rev. Bras.Agropec. Sustentável, 1, 151-161.

Camargo, A. C., Novaes, N. J., Novo, A. L. M., Mendonça, F. C., Manzano, A., Esteves, S. N., ... Faria, V. P. (2006a). Projeto Balde Cheio: Transferência de tecnologia na produção leiteira (Comunicado Técnico 73). Estudo de caso do sítio São Carlos, de Irapuru, SP.

Camargo, A. C., Novaes, N. J., Novo, A. L. M., Mendonça, F. C., Manzano, A., Esteves, S. N., ... Faria, V. P. (2006b). Projeto Balde Cheio: Transferência de tecnologia na produção leiteira (Comunicado Técnico 75). Estudo de caso do sítio São João, de Monte Castelo, SP.

CONAMA (Conselho Nacional De Meio Ambiente). (1986). Resolução Federal no 20 de 18.06.86.

Costa, T. V., Tarsitano, M. A. A., \& Conceição, M. A. F. (2012). Caracterização social e tecnológica da produção de uvas para mesa em pequenas propriedades rurais da região de Jales-SP. RevBras de Frutic, 34, 766-773. https://doi.org/10.1590/S0100-29452012000300016 
Diniz, E. R., Mouro, G. F., Lizarelli, P. H., Riguetto, C. S., Silva, F. A., \& Silva, E. S. (2014). Relato de experiência: Um diagnóstico participativo situacional da agricultura familiar no Território Vale do Ivaí sob a perspectiva da agroecologia. Cadernos de Agroecologia, 9, 4.

Eisenlord, S. D., Freedman, Z., Zak, D. R., Xue, K, He, Z., \& Zhou, J. (2013). Microbial mechanisms mediating increased soil C storage under elevated atmospheric N deposition. Appl Environ Microbiol., 79, 1191-1199. https://doi.org/10.1128/AEM.00468-13

EMBRAPA. (2016). Quem Somos. Retrieved from https://www.embrapa.br/quem-somos

Espíndola, H. (2005). Sertão do Rio Doce. Governador Valadares: Editora Univale.

Goldie, J., Douglas, B., \& Furnass, B. (2005). A urgent need to change direction. In J. Goldie, B. Douglas, B. Furnass (Eds.), In search of sustainability (pp. 1-16). CSIRO Publishing, Clayton, Austrália.

IBGE (Instituto Brasileiro de Geografia e Estatística). (2014). Produção da Pecuária Municipal, 42.

IBGE (Instituto Brasileiro de Geografia e Estatística). (2006). Censo Agropecuário 2006.

Janssens, I. A., Dieleman, W., \& Luyssaert, S. (2010). Reduction of forest soil respiration in response to nitrogen deposition. Nat. Geosci., 3, 315- 322. https://doi.org/10.1038/ngeo844

Jindaluang, W., Kheoruenromne, I., Suddhiprakarn, A., Singh, B. P., \& Singh, B. (2013). Influence of soil texture and mineralogy on organic matter content and composition in physically separated fractions soils of Thailand. Geoderma, 195-196, 207-219. https://doi.org/10.1016/j.geoderma.2012.12.003

Luna, N. R. S, Andrade, E. M., Crisóstomo, L. A., Meireles, A. C. M., \& Aquino, D. N. (2013). Dinâmica do nitrato e cloreto no solo e a qualidade das águas subterrâneas do distrito de irrigação Baixo Acaraú, CE. Rev Agro@mbiente On-line, 7(1),53-62. https://doi.org/10.18227/1982-8470ragro.v7i1.1042

Kempers, A. J., \& Zweers, A. (1986). Ammonium determination in soil extracts by the salicylate method. Comm. Soil Sci. Plant Anal., 17, 715-723. https://doi.org/10.1080/00103628609367745

Kuzyakov, Y. (2010). Priming effects: Interactions between living and dead organic matter. Soil Biol. \& Biochem., 42, 1363-1371. https://doi.org/10.1016/j.soilbio.2010.04.003

Kuzyakov, Y., Friedel, J. K., \& Stahra, K. (2000). Review of mechanisms and quantification of priming effects. Soil Biol. \& Biochem., 32, 1485-1498. https://doi.org/10.1016/S0038-0717(00)00084-5

Kuzyakov, Y., \& Jones, D. L. (2006). Glucose uptake by maize roots and its transformation in the rhizosphere. Soil Biol. and Biochem., 38, 851-860. https://doi.org/10.1016/j.soilbio.2005.07.012

Lal, R. (2008). Sequestration of atmospheric $\mathrm{CO}_{2}$ into global carbon pool. Energy Environ. Sci., 1, 86-100. https://doi.org/10.1039/b809492f

Lal, R., Miller, F. P., \& Logan, T. J. (1988). Are intensive agricultural practices environmentally and ethically sound? J. Agric. Environ. Ethics, 1, 193-210. https://doi.org/10.1007/BF01833409

Manzoni, S., Taylor, P., Richter, A., Porporato, A., \& Ågren, G. I. (2012). Environmental and stoichiometric controls on microbial carbon-use efficiency in soils: Research review. New Phytol., 196, 79-91. https://doi.org/10.1111/j.1469-8137.2012.04225.x

Marconi, M. A. E., \& Lakatos, E. M. (2003). Metodologia Cientifica (5th ed., p. 310). Atlas, São Paulo, São Paulo, Brasil.

Moura, L. G. V. (2002). Indicadores para a avaliação da sustentabilidade em sistemas de produção da agricultura familiar: $O$ caso dos fumicultores de GUDA-RS (p. 242, Dissertação de Mestrado, Programa de Pós Graduação em Desenvolvimento Rural, Universidade Federal do Rio Grande do Sul, Rio Grande do Sul, Brazil).

Moreira, F. M. S., \& Siqueira, J. O. (2006). Microbiologia e bioquímica do solo (2nd ed., p. 729). Universidade Federal de Lavras, Lavras, Brazil.

PNUD (Programa das Nações Unidas para o Desenvolvimento). (2013). Atlas do Desenvolvimento Humano no Brasil.

Rasse, D. P., Rumpel, C., \& Dignac, M. F. (2005). Is soil carbon mostly root carbon? Mechanisms for a specific stabilization. Plant and Soil, 269, 341-356. https://doi.org/10.1007/s11104-004-0907-y 
Ribeiro, A. C., Guimarães, P. T. G., \& Alvarez, V. V. H. (1999). Recomendações para o uso de corretivos e fertilizantes em Minas Gerais (5 Aproximação, p. 360). Comissão de Fertilidade do Solo do Estado de Minas Gerais, Viçosa, Brazil.

Rotz, C. A., Montes, F., \& Chianese, D. S. (2010). The carbon footprint of dairy production systems through partial life cycle assessment. J. Dairy Sci., 93(3), 1266-1282. https://doi.org/10.3168/jds.2009-2162

Rizzini, C. T. (1997). Tratado de fitogeografia do Brasil: Aspectos ecológicos, sociológicos e florísticos (2nd ed., p. 747). Âmbito Cultural Edições Ltda, Rio de Janeiro, Brazil.

Rusinamhodzi, L., Corbeels, M., Zingore, S., Nyamangara, J., \& Giller, K. E. (2013). Pushing the envelope? Maize production intensification and the role of cattle manure in recovery of degraded soils in smallholder farming areas of Zimbabwe. Field Crops Res., 147, 40-53. https://doi.org/10.1016/j.fcr.2013.03.014

Schulten, H. R., \& Schnitzer, M. (1998). The chemistry of soil organic nitrogen: A review. Biol Fertil Soils, 26, 1-15. https://doi.org/10.1007/s003740050335

Silva Filho, L. V. (2010). Qualidade e percepção ambiental: Estudo de caso da bacia hidrográfica do Rio Passauna (p. 218, Tese de Doutorado, Universidade Federal do Paraná, Curitiba, Brazil).

SISTEMA FAEMG. (2015). Agropecuária mineira-Balanço 2015/Perspectivas 2016.

SISTEMA FAEMG. (2017). Retrieved from http://www.sistemafaemg.org.br/Conteudo.aspx?Code=256\&Portal $=2 \&$ ParentCode $=15 \&$ ParentPath $=$ None $\&$ ContentVersion $=\mathrm{R}$

Tedesco, H. J., Volkweiss, S. J., \& Bohnen, H. (1985). Análises de solo, plantas e outros materiais. Boletim Técnico, 5 (p. 50). Universidade Federal do Rio Grande do Sul, Porto Alegre, Brazil.

Yang, J. E., Skogley, E. O., Schaff, B. E., \& Kim, J. J. (1998). A simple Spectrophotometric determination of nitrate in water, resin and soil extracts. Soil Sci Soc Am J, 62, 1108-1115. https://doi.org/10.2136/sssaj1998. $03615995006200040036 \mathrm{x}$

Yeomans, J. C., \& Bremner, J. M. (1998). A rapid and precise method for routine determination of organic carbon in soil. Comm. Soil Sci. Plant Anal., 19, 1467-1476. https://doi.org/10.1080/00103628809368027

Veloso, H. P., Rangel-Filho, A. L. R., \& Lima, J. C. (1991). Classificação da vegetação brasileira adaptada a um sistema universal. IBGE, Rio de Janeiro, Brazil.

Xavier, K. D., Marques, D. M. F., \& Camargo, A. M. M. (2012). A relevância da agricultura familiar segundo os dados do censo agropecuário de 2006: Uma análise comparativa entre os estados do Pará, Pernambuco, São Paulo e Rio Grande do Sul. Conjuntura Econômica Goiana, 21. 


\section{Appendix A}

Table A1. Chemical analysis and clay content of the soil, including unmanaged and managed pastures by the Balde Cheio Project, in the farmlands located in São Félix de Minas-MG, Brazil

\begin{tabular}{|c|c|c|c|c|c|c|c|c|c|}
\hline \multirow{2}{*}{\multicolumn{2}{|c|}{ Farmland Soil Layer $(\mathrm{cm})$}} & \multicolumn{2}{|c|}{$\mathrm{pH}$} & \multicolumn{2}{|c|}{$\mathrm{Al}^{3+}\left(\mathrm{cmol}_{\mathrm{c}} \mathrm{kg}^{-1}\right)$} & \multicolumn{2}{|c|}{$\mathrm{H}+\mathrm{Al}\left(\mathrm{cmol}_{\mathrm{c}} \mathrm{kg}^{-1}\right)$} & \multicolumn{2}{|c|}{ Clay (\%) } \\
\hline & & PNMBC & $\mathrm{BCP}$ & PNMBC & $\mathrm{BCP}$ & PNMBC & $\mathrm{BCP}$ & PNMBC & $\mathrm{BCP}$ \\
\hline \multirow{5}{*}{1} & $0-10$ & 5.80 & 6.70 & 0.03 & 0.03 & 3.00 & 0.60 & 10.00 & 10.70 \\
\hline & $10-20$ & 5.80 & 6.40 & 0.01 & 0.03 & 3.40 & 2.00 & 18.27 & 8.23 \\
\hline & $20-40$ & 5.90 & 6.40 & 0.01 & 0.00 & 1.60 & 0.80 & 25.34 & 14.27 \\
\hline & $40-60$ & 6.40 & 6.60 & 0.02 & 0.01 & 0.00 & 0.60 & 35.77 & 21.55 \\
\hline & $60-100$ & 6.30 & 5.20 & 0.00 & 0.99 & 0.00 & 2.40 & 32.85 & 18.84 \\
\hline \multirow{5}{*}{2} & $0-10$ & 5.20 & 5.90 & 0.16 & 0.00 & 5.80 & 1.60 & 11.87 & 5.98 \\
\hline & $10-20$ & 5.20 & 5.10 & 0.28 & 0.25 & 4.00 & 4.40 & 13.74 & 12.23 \\
\hline & $20-40$ & 4.90 & 4.50 & 1.90 & 1.10 & 6.20 & 6.40 & 16.59 & 16.15 \\
\hline & $40-60$ & 4.80 & 4.40 & 1.26 & 1.66 & 6.40 & 7.80 & 22.30 & 24.92 \\
\hline & $60-100$ & 4.80 & 4.60 & 1.00 & 1.50 & 5.00 & 7.00 & 31.23 & 25.12 \\
\hline \multirow{5}{*}{3} & $0-10$ & 5.90 & 6.40 & 0.03 & 0.00 & 0.60 & 0.00 & 4.86 & 3.78 \\
\hline & $10-20$ & 6.00 & 6.20 & 0.00 & 0.00 & 1.60 & 0.20 & 3.82 & 3.25 \\
\hline & $20-40$ & 6.30 & 6.10 & 0.00 & 0.03 & 0.20 & 0.80 & 4.91 & 3.91 \\
\hline & $40-60$ & 6.40 & 6.30 & 0.00 & 0.00 & 0.20 & 0.60 & 14.76 & 4.70 \\
\hline & $60-100$ & 6.70 & 5.70 & 0.05 & 0.00 & 0.00 & 0.20 & 24.47 & 4.45 \\
\hline \multirow{5}{*}{4} & $0-10$ & 6.20 & 6.70 & 0.00 & 0.05 & 1.80 & 0.80 & 2.98 & 8.04 \\
\hline & $10-20$ & 5.90 & 6.10 & 0.03 & 0.03 & 1.80 & 1.80 & 3.42 & 9.35 \\
\hline & $20-40$ & 5.90 & 5.50 & 0.03 & 0.03 & 1.80 & 3.00 & 4.13 & 9.87 \\
\hline & $40-60$ & 5.80 & 5.80 & 0.85 & 0.00 & 2.20 & 2.80 & 7.17 & 8.60 \\
\hline & $60-100$ & 5.70 & 6.00 & 0.03 & 0.05 & 1.80 & 1.00 & 3.68 & 10.96 \\
\hline \multirow{5}{*}{5} & $0-10$ & 6.00 & 6.50 & 0.03 & 0.00 & 2.20 & 1.80 & 11.65 & 13.21 \\
\hline & $10-20$ & 5.60 & 5.80 & 0.03 & 0.00 & 3.80 & 2.80 & 12.41 & 15.60 \\
\hline & $20-40$ & 5.30 & 5.70 & 0.15 & 0.00 & 3.80 & 3.40 & 8.87 & 16.74 \\
\hline & $40-60$ & 5.20 & 5.40 & 0.21 & 0.05 & 3.80 & 3.00 & 11.84 & 17.65 \\
\hline & $60-100$ & 5.40 & 5.40 & 0.03 & 0.05 & 3.00 & 2.60 & 17.21 & 28.91 \\
\hline
\end{tabular}

\section{Copyrights}

Copyright for this article is retained by the author(s), with first publication rights granted to the journal.

This is an open-access article distributed under the terms and conditions of the Creative Commons Attribution license (http://creativecommons.org/licenses/by/4.0/). 